\title{
DIALLEL ANALYSIS OF TOLERANCE TO DROUGHT IN COWPEA GENOTYPES $^{1}$
}

\author{
ERINA VITÓRIO RODRIGUES ${ }^{2}$, KAESEL JACKSON DAMASCENO-SILVA ${ }^{3 *}$, MAURISRAEL DE MOURA \\ ROCHA $^{3}$, EDSON ALVES BASTOS ${ }^{3}$, ADRIANO DOS SANTOS $^{4}$
}

\begin{abstract}
The low use of technologies by farmers and the occurrence of biotic and abiotic stresses are limiting factors for cowpea production in the Brazilian Northeast region. The tolerance of genotypes to drought is an alternative to decrease the negative effects of stresses on cowpea production. Thus, the objective of this work was to identify parents and combinations of cowpea genotypes with high probability of generating segregating populations with tolerance to drought. Six cowpea genotypes were crossed in a complete diallel cross design, totaling $30 \mathrm{~F}_{2}$ populations, which were evaluated together with their parents in an experiment under water deficit at the experimental field of the Embrapa Mid-North, Teresina, State of Piauí, Brazil. A triple lattice incomplete block experiment design was used, with three replications, with experimental plot consisting of six 2-m plant rows. Fifteen plants per plot were sampled to evaluate their agronomic characteristics, whose results were subjected to analysis of variance and means were used to estimate the general and specific combining abilities. The genotypes showed significant differences in all characteristics evaluated, denoting the genetic variability of the population. The additive effects were more important than the non-additive effects, and maternal inheritance was detected. The genotypes BRS Xiquexique, Pingo-de-Ouro-1 -2 and MNC99-510F-16-1 were the most promising for use in recurrent selection programs for tolerance to water deficit. The hybrid combinations (1) BRS Paraguaçu X (4) CNCx-698-128G, (2) Pingo-de-Ouro-1-2 X (3) BRS Xiquexique, (3) BRS Xiquexique X (5) Santo-Inácio, (4) CNCx-698-128G X (6) MNC99-510F-16-1 and (5) Santo-Inácio X (4) CNCX-698-128G showed potential for generating superior lineages regarding bean production and tolerance to water deficit.
\end{abstract}

Keywords: Vigna unguiculata L.. Combining ability. Plant breeding. Genetic potential.

\section{ANÁLISE DIALÉLICA DE GENÓTIPOS DE FEIJÃO-CAUPI VISANDO SELEÇÃO PARA TOLERÂNCIA À SECA}

RESUMO - A baixa adoção de tecnologias pelos agricultores e a ocorrência de estresses bióticos e abióticos são fatores que limitam a produção do feijão-caupi na região Nordeste do Brasil. A tolerância de genótipos à seca é uma das formas para diminuir os efeitos negativos dos estresses sobre a produtividade. O objetivo deste trabalho foi identificar genitores e combinações promissoras com maior probabilidade de gerarem populações segregantes de feijão-caupi tolerantes à seca. Foi realizado um dialelo completo envolvendo seis genótipos de feijão-caupi, totalizando 30 populações $F_{2}$, que foram avaliadas, juntamente com seus genitores, em um ensaio sob déficit hídrico, no campo experimental da Embrapa Meio-Norte, em Teresina-PI. Utilizou-se o delineamento experimental látice triplo, com parcela de 6 linhas de $2 \mathrm{~m}$, sendo amostradas 15 plantas por parcela. Foram avaliados caracteres agronômicos e submetidos à análise de variância e, utilizando-se das médias, obtiveram-se as estimativas de capacidade geral e específica de combinação. Observou-se diferenças significativas para todos os caracteres, evidenciando a existência de variabilidade genética na população. Os efeitos aditivos foram mais importantes que os efeitos não aditivos, sendo também constatada a presença de herança materna. Os genótipos BRS Xiquexique, Pingo de Ouro-1-2 e MNC99- 510F-16-1 foram os mais promissores para utilização em programa de seleção recorrente visando tolerância ao déficit hídrico. As combinações híbridas (1) BRS Paraguaçu X (4) CNCx 698-128G, (2) Pingo de Ouro-1-2 X (3) BRS Xiquexique, (3) BRS Xiquexique X (5) Santo Inácio, (4) CNCx 698-128G X (6) MNC99-510F-16-1 e (5) Santo Inácio X (4) CNCx 698-128G, possuem potencial simultâneos para extração de linhagens superiores quanto à produtividade de grãos e tolerantes ao déficit hídrico.

Palavras-chave: Vigna unguiculata L.. Capacidade de combinação. Melhoramento de plantas. Potencial genético.

\footnotetext{
*Corresponding author

${ }^{1}$ Received for publication in $08 / 14 / 2016$; accepted in 04/19/2017.

Paper approved from IV CONAC 2016.

Paper extracted from the master's thesis of the first author

${ }^{2}$ Postgraduate Program in Genetics and Breeding, Universidade Federal do Piauí, Teresina, PI, Brazil; erinavict@hotmail.com.

${ }^{3}$ Embrapa Meio-Norte, Teresina, PI, Brazil; kaesel.damasceno@embrapa.br, maurisrael.rocha@embrapa.br, edson.bastos@embrapa.br.

${ }^{4}$ Genetics and Plant Breeding Laboratory, 1, Universidade Estadual do Norte Fluminense Darcy Ribeiro; Campos dos Goytacazes, RJ, Brazil; adriano.agro84@yahoo.com.br.
} 


\section{INTRODUCTION}

Cowpea (Vigna unguiculata (L.) Walp.) of african origin, and was first brought to the state of Bahia, Brazil, in the second half of the $16^{\text {th }}$ century by Portuguese colonizers and then spread across the country (FREIRE FILHO, 1988). It is grown in 97 tropical and subtropical countries of Africa, Asia, America, Europe and Oceania (FREIRE FILHO et al., 2011). Cowpea is an important food, rich in proteins, carbohydrates, vitamins, minerals and dietary fibers (FROTA et al., 2008; FREIRE FILHO et al., 2011), thus, it is grown mainly for production of grains for human consumption, as fresh, canned and dehydrated products (FREIRE FILHO; LIMA; RIBEIRO, 2005).

Cowpea is an important agricultural product in Brazil, whose production generate jobs and result in a staple food for rural and urban populations of the Brazilian North and Northeast regions (FREIRE FILHO et al., 2011). The world's largest producers of cowpea in 2014 were Nigeria (2.1 million tonnes), Niger (1.6 million tonnes) (FAO, 2017) and Brazil, whose production data is not presented by the FAO, which probably did not distinguish the Brazilian common bean and cowpea productions. The Brazilian cowpea production in 2015/2016 was $649,000 \mathrm{Mg}$, most of it in the Northeast region $(376,700 \mathrm{Mg})$, however, the cowpea yield in Brazil is low (338 kg ha-1) (CONAB, 2017), which shows the need for investments on technology. The cowpea yield in the Brazilian Center-West is $1,285 \mathrm{~kg} \mathrm{ha}^{-1}$, above the national average, especially due to the high technological management applied to crops in this region. The selection of tolerant genotypes to drought is one of the alternatives to minimize the effects of stresses on yield, which is confirmed by several works (BASTOS et al., 2011; MUCHERO et al., 2013; ABED et al., 2014).

Most cowpea crops in Brazil are conducted under rainfed conditions, subjecting the crops to risks of dry spells and rainfall below the required levels throughout the crop cycle. Water deficit is the most limiting abiotic factor for increasing cowpea production in Brazil. The main challenge for grain production has been to prevent losses due to water deficit, which is the most limiting environmental factor for crop production around the world, especially in semiarid regions (FRITSCHE-NETO; BORÉM, 2011). The low use of technologies by farmers and the occurrence of biotic and abiotic stresses are limiting factors for cowpea production in the Brazilian Northeast region.

Selection of parents is one of the most important stages in breeding programs involving crosses, since the success of a breeding program is related to the segregating potential of the populations generated by the crossings (KUREK et al., 2001), which is the combining abilities of their parents. Thus, identifying superior crosses is a fundamental step in the breeding process (KOTZAMANIDIS et al., 2008). Moreover, information on the genetic potential of crosses obtained by more than one method, allows us to direct efforts and financial resources to the more promising ones. One of the techniques that assists in choosing these crosses is the diallel crosses, which is based on their genetic values and considers their ability to combine in hybrids that produce promising segregating populations (RAMALHO et al., 2012b).

The purpose of diallel analyses is to assess the genetic design, estimating useful parameters in the selection of parents for crosses, and explain the genetic effects involved in determining their characteristics. The most commonly used method is the one proposed by Griffing (1956), which estimates the general combining ability (GCA) and specific combining ability (SCA) of the genotypes from diallel crosses. The first measures the relative performance of a lineage in a series of crosses and is associated with additive genetic effects; and the second characterizes the performance of specific hybrid combinations in relation to the average of their parents and is related to the effects of dominance, epistasis and various types of allelic interactions (CRUZ; REGAZZI; CARNEIRO, 2012).

Thus, the objective of this work was to identify parents and combinations of cowpea genotypes with high probability of generating segregating populations with tolerance to drought.

\section{MATERIAL AND METHODS}

The cowpea populations were obtained by crosses between six genotypes (Table 1), previously selected based on studies of tolerance to drought (BASTOS et al., 2011; NASCIMENTO et al., 2011).

A complete diallel cross design was used, adopting the Method-1 of the model proposed by Griffing (1956). Seeds of the $30 F_{1}$ hybrids were sowed (3 seeds per pit) and a thinning was carried out after the emergence, leaving only one plant per pit, which grew under screen cover, to obtain the $F_{2}$ population. Cultural practices were carried out according to the recommendations for the crop (FREIRE FILHO; LIMA; RIBEIRO, 2005). 
E. V. RODRIGUES et al.

Table 1. Characteristics of the six cowpea genotypes used in the diallel crosses.

\begin{tabular}{lllccc}
\hline & \multicolumn{1}{c}{ Genotype } & Origin & Growth habit & $\begin{array}{c}\text { 100 grains } \\
\text { weight (g) }\end{array}$ & $\begin{array}{c}\text { Response to } \\
\text { deficit }\end{array}$ \\
\hline 1 & BRS Paraguaçu & Embrapa Mid-North & Semi-prostrate & 17.0 & Tolerant \\
2 & Pingo-de-Ouro-1-2 & Embrapa Mid-North & Semi-prostrate & 26.6 & Tolerant \\
3 & BRS Xiquexique & Embrapa Mid-North & Semi-prostrate & 16.5 & Tolerant \\
4 & CNCx-698-128G & Embrapa Rice and Beans & Semi-prostrate & 14.7 & Tolerant \\
5 & Santo-Inácio & Picos, Piauí, Brazil & Semi-prostrate & 21.3 & Sensitive \\
6 & MNC99-510F-16-1 & Embrapa Mid-North & Semi-prostrate & 20.1 & Tolerant \\
\hline
\end{tabular}

The evaluation of the $30 \quad \mathrm{~F}_{2}$ populations (Table 2) and their parents was conducted in the experimental area of the Brazilian Agricultural Research Corporation (Embrapa Mid-North) in Teresina, State of Piauí, Brazil $\left(05^{\circ} 05^{\prime} \mathrm{S}, 42^{\circ} 48^{\prime} \mathrm{W}\right.$ and $74.4 \mathrm{~m}$ ), from July 26 to October 11,2011 . The region has annual average relative humidity of $77.02 \%$, annual precipitation of $1,388.9 \mathrm{~mm}$, and annual average air temperature of $26.97^{\circ} \mathrm{C}(22.08$ to $33.52{ }^{\circ} \mathrm{C}$ ). The climate of the region is Aw (tropical with wet and dry seasons) according to the classification of Köppen. The soil of the experimental area was classified as Ultisol (eutrophic
Yellow Argissolo - SiBCS) of sandy loam surface texture.

A triple lattice incomplete block experiment design was used, with three replications. The experimental plots consisted of six 2-m rows, with spacing of $1.0 \mathrm{~m}$ between rows and $0.50 \mathrm{~m}$ between plants. Three seeds were sowed per pit and a thinning was performed 15 days after sowing (DAS), leaving one plant per pit, which were properly labeled at the pre-flowering phase to evaluations. Manual weeding was performed during the crop conduction. Cultural practices were carried out to keep the area free from insects and diseases.

Table 2. Hybrid combinations of the cowpea genotypes evaluated under water deficit.

\begin{tabular}{clrlllll}
\hline No & & \multicolumn{2}{c}{ Genotypes } & No & & Genotypes \\
\hline 7 & BRS Paraguaçu & x & Pingo-de-Ouro-1-2 & 22 & CNCx-698-128G & x & BRS Paraguaçu \\
8 & BRS Paraguaçu & x & BRS Xiquexique & 23 & CNCx-698-128G & x & Pingo-de-Ouro-1-2 \\
9 & BRS Paraguaçu & x & CNCx-698-128G & 24 & CNCx-698-128G & x & BRS Xiquexique \\
10 & BRS Paraguaçu & x & Santo-Inácio & 25 & CNCx-698-128G & x & Santo-Inácio \\
11 & BRS Paraguaçu & x & MNC99-510F-16-1 & 26 & CNCx-698-128G & x & MNC99-510F-16-1 \\
12 & Pingo-de-Ouro-1-2 & x & BRS Paraguaçu & 27 & Santo-Inácio & x & BRS Paraguaçu \\
13 & Pingo-de-Ouro-1-2 & x & BRS Xiquexique & 28 & Santo-Inácio & x & Pingo-de-Ouro-1-2 \\
14 & Pingo-de-Ouro-1-2 & x & CNCx-698-128G & 29 & Santo-Inácio & x & BRS Xiquexique \\
15 & Pingo-de-Ouro-1-2 & x & Santo-Inácio & 30 & Santo-Inácio & x & CNCx-698-128G \\
16 & Pingo-de-Ouro-1-2 & x & MNC99-510F-16-1 & 31 & Santo-Inácio & x & MNC99-510F-16-1 \\
17 & BRS Xiquexique & x & BRS Paraguaçu & 32 & MNC99-510F-16-1 & x & BRS Paraguaçu \\
18 & BRS Xiquexique & x & Pingo-de-Ouro-1-2 & 33 & MNC99-510F-16-1 & x & Pingo-de-Ouro-1-2 \\
19 & BRS Xiquexique & x & CNCx-698-128G & 34 & MNC99-510F-16-1 & x & BRS Xiquexique \\
20 & BRS Xiquexique & x & Santo-Inácio & 35 & MNC99-510F-16-1 & x & CNCx-698-128G \\
21 & BRS Xiquexique & x & MNC99-510F-16-1 & 36 & MNC99-510F-16-1 & x & Santo-Inácio \\
\hline
\end{tabular}

A fixed conventional sprinkler system was used for irrigation, with sprinklers in lateral rows (spaced 12x12 m apart), pressure of $250 \mathrm{kPa}$, nozzle diameter of $3.4 \times 2.6 \mathrm{~mm}$ and flow rate of $1.07 \mathrm{~m}^{3} \mathrm{~h}^{-1}$. Irrigation was performed daily, according to the crop water requirement, calculated by the reference evapotranspiration $\left(\mathrm{ET}_{0}\right)$ (data from an automatic meteorological station of the EMBRAPA Mid-North) and the crop coefficient
(Kc) (0.6 to 1.1 depending on the phenological stage). The irrigation time was calculated with a spreadsheet describing the daily $\mathrm{ET}_{0}$ and precipitation. Two sets of sixteen water collectors were equally distributed in the experimental area. The water deficit was induced by suspending the irrigation from the pre-flowering (35 DAS) to the reproductive stage (49 DAS).

Soil moisture was monitored with a 
capacitance probe (DIVINER $2000^{\circledR}$ ), using 6 access tubes inserted to a depth of $0.70 \mathrm{~m}$, with readings at each $0.10 \mathrm{~m}$ of soil depth. The soil water retention curve of the experimental area (depths of 0.0 to $0.4 \mathrm{~m})$ was determined using the model of Genuchten (1980). The field capacity (FC) and permanent wilting point (PWP) found were $0.212 \mathrm{~cm}^{3} \mathrm{~cm}^{-3}$ and $0.905 \mathrm{~cm}^{3} \mathrm{~cm}^{-3}$, respectively.

The data were collected in 15 random plants. Correlation analysis with the Pearson's linear correlation coefficient was used to identify characteristics correlated positively with grain production. The evaluated characteristics were number of days for maturation (NDM) (number of days from sowing to the first pod with color change, indicating the beginning of the drying process), number of peduncles per plant (NPeP) (evaluated in 15 plants per plot), number of pods per plant (NPoP) (evaluated in 15 plants per plot), pod weight per plant (PWP) (weight of pods of each plot) (g), grain production (GP) (grain weight from 15 plants per plot) (g), 100-grain weight (100GW) (weight of 100 grains from each plant of each plot) $(\mathrm{g})$.

Six parents and $30 \mathrm{~F}_{2}$ populations, obtained from diallel crosses, including reciprocal ones, were used in the diallel analysis. The analyzes of combining ability were carried out according to the Method-1 of Griffing (1956), unfolding the effects of treatments into general combining ability (GCA), specific combining ability (SCA) and reciprocal effect (RE), considering the model described by Equation 1,

$$
Y_{i j}=m+g_{i}+g_{j}+s_{i j}+r_{i j}+e_{i j}
$$

wherein: $Y_{i j}$ is the average value of the hybrid $(i \neq j)$ or parent $(i=j)$ combination; $m$ is the overall average; $g_{i}, g_{j}$ are the effects of the GCA of the $i^{\text {th }}$ and $j-{ }^{\text {th }}$ parent $(i, j=1,2, \ldots, 6) ; s_{i j}$ is the effect of the SCA of crosses between parents of the order $i$ and $j$; $r_{i j}$ is the reciprocal effect that measures the differences provided by the parent $i$, or $j$, when used as male or female in crossing $i j$; and $e_{i j}$ is the average experimental error of the observation of order $i j$.

The quadratic components $(\Phi)$, which express the variability of the fix genotype, in terms of GCA, SCA and RE, were estimated by the Equations 2, 3 and 4:

$$
\begin{aligned}
& \Phi_{\mathrm{g}}=\frac{\mathrm{QMG}-\mathrm{QMR}}{2 \mathrm{p}} \\
& \Phi_{\mathrm{s}}=\mathrm{QMS}-\mathrm{QMR} \\
& \Phi_{\mathrm{rc}}=\mathrm{QMRC}-\mathrm{QMR}
\end{aligned}
$$

\section{RESULTS AND DISCUSSION}

The effects of the genotypes were significant $(p \leq 0.01)$ for all variables evaluated, which denotes the genetic variability of this population for these variables, and indicates the possibility of success in selecting superior genotypes tolerant to drought using this population as base (Table 3 ).

Variability for number of days for flowering, pod length (PL), PWP, 100GW, number of grains per pod (NGP), NPoP and GP, in populations from diallel crosses have been reported by Ushakumari, Vairan and Malini (2010); Carvalho et al. (2012) and Idahosa and Alika (2013). This result suggests that diallel crosses is a viable alternative for the expansion of the genetic base of cowpea and obtaining of superior segregating populations.

Table 3. Analysis of variance of number of days for maturity (NDM), number of peduncle per plant (NPeP), number of pods per plant (NPoP), pod weight per plant (PWP), grain production (GP) and 100-grain weight (100GW) of cowpea genotypes (six parents, their respective $\mathrm{F}_{2}$ populations and reciprocals).

\begin{tabular}{ccccccrr}
\hline \multirow{2}{*}{ Sources of variation } & \multicolumn{7}{c}{ Mean squares } \\
\cline { 2 - 7 } & DF & NDM & NPeP & NPoP & PWP & GP & $100 \mathrm{GW}$ \\
\hline Treatment & 35 & $1.8^{* *}$ & $55.8^{* *}$ & $136.0^{* *}$ & $1489.05^{* *}$ & $202057.7^{* *}$ & $18.1^{* *}$ \\
GCA & 5 & $0.5^{* *}$ & $78.2^{* *}$ & $219.0^{* *}$ & $748.7^{\text {ns }}$ & $79008.8^{\text {ns }}$ & $100.6^{* *}$ \\
SCA & 15 & $0.7^{* *}$ & $40.2^{* *}$ & $94.8^{* *}$ & $1127.0^{* *}$ & $165894.5^{* *}$ & $6.1^{* *}$ \\
RE & 15 & $1.4^{* *}$ & $63.9^{* *}$ & $149.4^{* *}$ & $2097.8^{* *}$ & $279237.3^{* *}$ & $2.6^{*}$ \\
Error & 55 & 0.3 & 11.1 & 24.7 & 316.1 & 41405.0 & 0.8 \\
$\Phi_{\mathrm{g}}$ & & 0.16 & 5.6 & 16.19 & 36.05 & 3133.65 & 8.31 \\
$\Phi_{\mathrm{s}}$ & & 0.4 & 29.1 & 70.1 & 810.9 & 124485.5 & 3.5 \\
$\Phi_{\mathrm{rc}}$ & & 0.55 & 26.4 & 62.35 & 890.85 & 118916.15 & 0.9 \\
\hline
\end{tabular}

$\mathrm{GCA}=$ general combining ability; $\mathrm{SCA}=$ specific combining ability; $\mathrm{RE}=$ reciprocal effect; $\mathrm{DF}=$ degrees of freedom. 
GCA represents the performance of parents when one lineage is crossed with another, and is related to the additive action of their genes. GCA has been used to choose parents in breeding programs. SCA represents deviations from the expected performance based on the GCA, and measurements of non-additive genetic effects. Hybrid combinations with favorable estimates of SCA, involving at least one of the parents with favorable GCA effect, are of interested for breeders (CRUZ; REGAZZI; CARNEIRO, 2012). Thus, crosses with high SCA and at least one parent with positive GCA are selected.

The significant effects for GCA and SCA found denotes that both additive and non-additive genetic effects are involved in controlling the NDM, NPeP, NPoP and $100 \mathrm{GW}$ of plants under water stress. The NDM, NPeP, NPoP and 100GW had significant effect for GCA, denoting a strong effect of additive genetic effects on their expression, and showing the high concentration of favorable alleles. This result also shows that there is at least one parent superior to the others regarding their average performance in hybrid combinations. Carvalho et al. (2012) evaluated eight cowpea genotypes and also found additive effects more important than non-additive for PL, PWP, NGP, NPoP, 100GW, and GP, making it possible to obtain gains directly from the selection.

The additive genetic variance was also found as the most relevant component for NPeP, NPoP and $100 \mathrm{GW}$ by Sibiya et al. (2011), since the effects of GCA were greater than the effects of SCA, showing its predominance in the control of these variables. Thus, in the present work, the selection of plants with desirable characteristics will result in progenies of high performance (THANH et al., 2010), since the presence of additive effects of the genes makes the average of the parents equal to the averages of $F_{1}, F_{2}$ and so on (RAMALHO et al., 2012a).

The reciprocal effect was significant $(p \leq 0.01)$ for all characteristics evaluated. This significance has implications on the estimation of genetic effects. The reciprocal effect can be divided into maternal and non-maternal effects (WU; MATHESON, 2001). Maternal effects are due to cytoplasmic genetic factors, and non-maternal effects are due to interactions between the effects of nuclear genes and cytoplasmic genes (MUKANGA; DERERA; TONGOONA, 2010). This information is very important in breeding programs, since defining which parent will be used as female or male is fundamental when there is a reciprocal effect.

The selection of parents is based on GCA estimates (positive estimates of high magnitude), since they contribute to increase the expression of their characteristics. However, for precocity, represented by the NDM, we search for parents who present negative estimates of high magnitudes, contributing to reduce the expression of this characteristic. Thus, the most promising genotypes were BRS Paraguaçu, BRS Xiquexique and CNCX-698-128G (Table 4).

GCA were negative for NPoP for the genotypes Pingo-de-Ouro-1-2 and Santo-Inácio, indicating that they should not participate in a cross-breeding for increasing the NPoP. The genotypes BRS Xiquexique and CNCx-698-128G had the highest GCA for NPoP, indicating the presence of genes with favorable additive effects for the expression of this variable, and the possibility of gains for NPoP, and also for BP due to the positive correlation between NPoP and GP (CARVALHO et al., 2012).

Table 4. General combining ability (GCA) for number of days for maturity (NDM), number of peduncles per plant (NPeP), number of pods per plant (NPoP), pod weight per plant (PWP), grain production (GP) and 100-grains weight (100GW) of the six cowpea genotypes, evaluated under water stress.

\begin{tabular}{lcccccc}
\hline \multicolumn{1}{c}{ Parents } & NDM & NPeP & NPoP & PWP & GP & $100 \mathrm{GW}$ \\
\hline BRS Paraguaçu & -0.29 & -1.62 & 0.17 & -4.10 & -35.11 & -0.57 \\
Pingo-de-Ouro-1-2 & 0.29 & -0.47 & -2.71 & -3.47 & -34.26 & 2.99 \\
BRS Xiquexique & -0.51 & -0.28 & 1.60 & 4.64 & 47.35 & -0.70 \\
CNCx-698-128G & -0.28 & 2.45 & 3.68 & 2.24 & -7.14 & -2.03 \\
Santo-Inácio & 0.61 & -0.90 & -2.61 & -4.5 & -39.49 & 0.07 \\
MNC99-510F-16-1 & 0.17 & -0.93 & -0.13 & 5.25 & 68.65 & 0.24 \\
\hline
\end{tabular}

The genotypes BRS Xiquexique, CNCx-698-128G and MNC99-510F-16-1 showed high and positive GCA estimates for PWP Carvalho et al. (2012), also found positive PWP in the cultivar BRS Xiquexique. The genotypes BRS Paraguaçu, Pingo-de-Ouro-1-2 and Santo-Inácio should not be used in breeding programs for PWP, since they had negative GCA estimates of high magnitude.
The genotypes BRS Xiquexique and MNC99-510F-16-1 stood out for improvement of genotypes regarding their GP, since they had GCA with positive estimates of high magnitudes. The genotypes that contributed to reduce the expression of GP were BRS Paraguaçu, CNCx-698-128G and Santo-Inácio, which are not recommended for breeding programs for GP gains. The genotype 
Pingo-de-Ouro-1-2 stood out regarding the $100 \mathrm{GW}$, with GCA of 2.99, thus, it is the most recommended genotype to be used in blocks of crosses to increase the average bean weight. Breeding programs have been searching for gains in $100 \mathrm{GW}$, since this is a requirement of the market (FREIRE FILHO et al., 2011).

SCA represents deviations of a hybrid from the expected performance, based on the GCA of their parents. High SCA are found in more dissimilar genotypes regarding frequencies of genes with dominance, although they are also affected by the average gene frequency of the diallel. Positive SCA indicate the negative heterosis of the parents and negative SCA indicate their varietal heterosis, with negative one-way dominance deviations, i.e., heterosis manifested by reducing the expression of the characteristic (CRUZ; REGAZZI; CARNEIRO, 2012). Thus, according to Abreu, Ramalho and
Santos (2002), high SCA are important for obtaining promising segregating populations, due to the release of a greater variability, which is essential in the selection process.

The effects of SCA, although useful in indicating the best hybrid combinations, do not show whether the performance of the hybrids can be altered by using either male or female parents, which is performed by estimates of reciprocal effects. Thus, when the BRS Paraguaçu is used as female and CNCx-698-128G as male, GP can increase by $191.42 \mathrm{~kg}$; and when the genotype CNCx-698-128G is used as female and BRS Paraguaçu as male, GP can decrease by $73.24 \mathrm{~kg}$. Moreover, crosses between Santo-Inácio as female with CNCx-698-128G and Pingo-de-Ouro-1-2 are the most promising, since they aggregate on average 8 pods per plant, 35 grams in pod weight per plant and $433 \mathrm{~kg}$ in bean production (Table 5).

Table 5. Specific combining ability (SCA) and reciprocal effect for number of days for maturity (NDM), number of peduncles per plant (NPeP), number of pods per plant (NPoP), pod weight per plant (PWP), grain production (GP) and 100 -grain weight $(100 \mathrm{GW})$ of cowpea from crosses of six genotypes, evaluated under water stress.

\begin{tabular}{|c|c|c|c|c|c|c|}
\hline \multirow{2}{*}{$\begin{array}{c}\text { Crossing } \\
+\mathrm{x} \hat{\diamond}\end{array}$} & \multicolumn{6}{|c|}{ Characteristic } \\
\hline & NDM & $\mathrm{NPeP}$ & NPoP & PWP & GP & 100GW \\
\hline $1 \times 1$ & 0.90 & -1.85 & -2.70 & -3.01 & -59.90 & 0.50 \\
\hline $1 \times 2$ & -0.01 & 0.01 & -1.64 & -8.62 & -90.22 & -1.25 \\
\hline $1 \times 3$ & -0.04 & -1.53 & -263 & -6.25 & -77.21 & -0.70 \\
\hline $1 \times 4$ & -0.40 & 2.68 & 5.31 & 12.82 & 191.42 & -0.18 \\
\hline $1 \times 5$ & -0.20 & -0.12 & 0.25 & -0.32 & -27.33 & 0.83 \\
\hline $1 \times 6$ & -0.26 & 0.80 & 1.40 & 5.39 & 63.25 & 0.80 \\
\hline $2 \times 1$ & -0.40 & -1.37 & -1.63 & -7.45 & -54.98 & 0.06 \\
\hline $2 \times 2$ & 0.48 & 4.56 & 6.00 & 24.63 & 310.00 & 0.63 \\
\hline $2 \times 3$ & 0.14 & 1.87 & 3.81 & 15.38 & 178.65 & -0.27 \\
\hline $2 \times 4$ & -0.09 & -6.36 & -8.52 & -32.48 & -405.43 & 0.42 \\
\hline $2 \times 5$ & -0.11 & 0.71 & -0.65 & -0.90 & -7.19 & 0.86 \\
\hline $2 \times 6$ & -0.40 & 0.62 & 1.00 & 1.98 & 14.19 & -0.39 \\
\hline $3 \times 1$ & -0.50 & -0.73 & -0.77 & -10.03 & -109.84 & -0.36 \\
\hline $3 \times 2$ & 0.14 & 1.90 & 2.40 & 11.03 & 162.09 & -1.24 \\
\hline $3 \times 3$ & 0.08 & -4.33 & -5.30 & -21.09 & -198.63 & -0.69 \\
\hline $3 \times 4$ & -0.62 & -0.41 & 5.14 & 10.87 & 86.89 & 0.37 \\
\hline $3 \times 5$ & 0.09 & 1.06 & 0.42 & 1.56 & 22.26 & -0.35 \\
\hline $3 \times 6$ & 0.36 & -0.13 & -1.45 & -0.48 & -11.90 & 1.63 \\
\hline $4 \times 1$ & -0.04 & -0.90 & -4.90 & -5.32 & -73.24 & 0.31 \\
\hline $4 \times 2$ & -0.60 & -1.07 & -0.60 & -6.13 & -56.02 & -0.63 \\
\hline $4 \times 3$ & -0.10 & -0.41 & -1.65 & 7.05 & 36.12 & 0.47 \\
\hline $4 \times 4$ & 0.75 & 0.70 & -2.58 & -9.68 & -103.48 & -1.83 \\
\hline $4 \times 5$ & 0.16 & -0.11 & 0.11 & 10.38 & 124.61 & 1.45 \\
\hline $4 \times 6$ & 0.20 & 0.02 & 0.54 & 8.06 & 105.98 & -0.23 \\
\hline $5 \times 1$ & 0.54 & 1.16 & -0.17 & 2.11 & 11.40 & -1.20 \\
\hline $5 \times 2$ & 0.47 & 5.00 & 6.97 & 31.49 & 390.59 & -0.49 \\
\hline $5 \times 3$ & -0.27 & 3.36 & 5.37 & 17.98 & 174.50 & 0.37 \\
\hline $5 \times 4$ & 0.10 & 6.60 & 10.93 & 39.73 & 476.64 & 0.07 \\
\hline $5 \times 5$ & 0.09 & -2.25 & -4.17 & -15.58 & -186.03 & -1.12 \\
\hline $5 \times 6$ & -0.03 & 2.14 & 4.03 & 4.86 & 73.69 & -1.66 \\
\hline $6 \times 1$ & -0.70 & -4.57 & -5.60 & -19.38 & -199.23 & 0.15 \\
\hline $6 \times 2$ & 0.47 & -1.40 & -2.43 & -13.69 & -165.12 & -1.01 \\
\hline $6 \times 3$ & -0.30 & -6.50 & -9.77 & -35.49 & -379.72 & 0.40 \\
\hline $6 \times 4$ & -0.17 & 2.20 & 2.70 & 9.73 & 94.06 & 0.05 \\
\hline $6 \times 5$ & -0.57 & -0.73 & -0.44 & -5.94 & -128.83 & -1.13 \\
\hline $6 \times 6$ & 0.12 & -3.45 & -5.35 & -19.85 & -245.21 & -0.16 \\
\hline
\end{tabular}


The crosses (2) Pingo-de-Ouro-1-2 X (1) BRS Paraguaçu, (3) BRS Xiquexique X (4) CNCX-698-128G and (4) CNCx-698-128G X (2) Pingo-de-Ouro-1-2 had favorable SCA for precocity (NDM). They had at least one GCA negative parent. In this context, it is worth mentioning that in the crossing (3) BRS Xiquexique $\mathrm{X}$ (4) CNCx-698-128G, both parental had negative GCA, i.e., both contributed to reduce the NDM.

\section{CONCLUSIONS}

The additive gene effects are more important than the non-additive gene effects.

The selection of female or male parents for crosses is important for selection of genotypes tolerant to drought.

The results found are fundamental for breeding programs, since defining which parent will be used as female and male is essential when a reciprocal effect is found.

The genotypes BRS Xiquexique, Pingo-de-Ouro-1-2 and MNC99-510F-16-1 are the most promising to be used in a recurrent selection program for tolerance to drought.

The hybrid combinations (1) BRS Paraguaçu X (4) CNCx-698-128G, (2) Pingo-de-Ouro-1-2 X (3) BRS Xiquexique, (3) BRS Xiquexique $X$ (5) Santo-Inácio, (4) CNCX-698-128G X (6) MNC99-510F-16-1 and (5) Santo-Inácio X (4) CNCx-698-128G, have potential for generating superior lineages regarding grain production and tolerance to water deficit.

\section{ACKNOWLEDGEMENTS}

The authors thank the Brazilian Agricultural Research Corporation (EMBRAPA Meio-Norte) and the Brazilian National Council for Scientific and Technological Development (CNPq) (Processes: 485350/2013-0 e 308172/2013-2) for financial support for this project, and the Coordination for the Improvement of Higher Education Personnel (CAPES) for the scholarship.

\section{REFERENCES}

$\mathrm{ABED}, \mathrm{Z}$. A. et al. Breeding for drought tolerance in progenies of cowpea (Vigna unguiculata (L.) Walp). Journal of Experimental Biology and Agricultural Sciences, Didwana, v. 2, n. 5, p. 489494, 2014.

ABREU, A. F. B.; RAMALHO, M. A. P.; SANTOS, J. B. Prediction of seed-yield potential of common bean populations, Genetics and Molecular Biology,
Ribeirão Preto, v. 25, n. 3, p. 323-327, 2002.

BASTOS, E. A. et al. Identification of cowpea genotypes for drought tolerance. Revista Ciência Agronômica, Fortaleza, v. 42, n. 1, p. 100-107, 2011.

CARVALHO, L. C. B. et al. Phenotypic correlations between combining abilities of F2 cowpea populations. Crop Breeding and Applied Biotechnology, Viçosa, v. 12, n. 3, p. 211-214, 2012.

COMPANHIA NACIONAL DE ABASTECIMENTO - CONAB. Sexto levantamento de safras brasileiras de grãos, março 2017. Disponível em: $<$ http:// www.conab.gov.br/OlalaCMS/uploads/ arquivos/17_03_14_15_28_33_boletim_graos_marc o_2017bx.pdf $>$. Acesso em: 29 mar. 2017.

CRUZ, C. D.; REGAZZI, A. J.; CARNEIRO, P. C. Métodos biométricos aplicados ao melhoramento genético. 4. ed. Viçosa, MG: UFV, 2012, 414 p.

FOOD AND AGRICULTURE ORGANIZATION OF THE UNITED NATIONS - FAO. FAOSTAT. Crops. Cow peas, dry. Disponível em: $<$ http:// www.fao.org/faostat/en/\#data/QC/visualize>. Acesso em: 29 mar. 2017.

FREIRE FILHO, F. R. Origem, evolução e domesticação do caupi. In: ARAÚJO, J. P. P.; WATT, E. E. O caupi no Brasil. Brasília: IITA/ Embrapa, 1988. cap. 1, p. 27-46.

FREIRE FILHO, F. R. et al. Feijão-caupi: produção, melhoramento genético, avanços e desafios. Teresina PI: Embrapa Meio-Norte, 2011. 84 p.

FREIRE FILHO, F. R.; LIMA, J. A. A.; RIBEIRO, V. Q. Feijão-caupi: avanços tecnológicos. Brasília, DF: Embrapa Informação Tecnológica, 2005. 519 p.

FRITSCHE-NETO, R.; BORÉM, A. Melhoramento de plantas para condições de estresses abióticos. Viçosa, MG: UFV, 2011. 240 p.

FROTA, K. M. G. et al. Cholesterol-Lowering Properties of Whole Cowpea Seed and Its Protein Isolate in Hamsters. Journal of Food Science, Champaign, v. 73, n. 9, p. 235-240, 2008.

GENUCHTEN, M. T. A closed-form equation for predicting hydraulic conductivity of unsaturated soils. Soil Science Society of American Journal, Madison, v. 44, n. 5, p. 892-898, 1980.

GRIFFING, B. Concept of general and specific ability in relation to diallel crossing systems. 
Australian Journal of Biological Sciences, Melbourne, v. 9, n. 4, p. 462-493, 1956.

IDAHOSA, D. O.; ALIKA, J. E. Diallel analysis of six agronomic characters in Vigna unguiculata genotypes, African Journal of Plant Breeding, Asokoro, v. 1, n. 1, p. 1-7, 2013.

KOTZAMANIDIS, S. T. et al. Prediction criteria of promising $\mathrm{F} 3$ populations in durum wheat: a comparative study. Field Crops Research, Amsterdam, v. 107, n. 3, p. 257-264, 2008.

KUREK, A. J. et al. Capacidade combinatória como critério de eficiência na seleção de genitores em feijoeiro. Pesquisa Agropecuária Brasileira, Brasília, v. 36, n. 4, p. 645-651, 2001.

MUCHERO, W. et al. Genetic architecture of delayed senescence, biomass, and grain yield under drought stress in cowpea. PLoS ONE, San Francisco, v. 8, n. 7, p. e70041, July 2013. Disponível em: <https:// www.ncbi.nlm.nih.gov/pmc/articles/PMC3728364/ pdf/pone.0070041.pdf>. Acesso em: 24 jul. 2017.

MUKANGA, M.; DERERA, J.; TONGOONA, P. Gene action and reciprocal effects for ear rot resistance in crosses derived from five tropical maize populations. Euphytica, Wageningen, v. 174, n. 2, p. 293-301, 2010.

NASCIMENTO, S. P. et al. Tolerância ao déficit hídrico em genótipos de feijão-caupi. Revista Brasileira de Engenharia Agrícola e Ambiental, Campina Grande, v. 15, n. 8, p. 853-860, 2011.

RAMALHO, M. A. P. et al. Genética na Agropecuária. 5. ed. Lavras MG: UFLA, 2012a. $566 \mathrm{p}$.

RAMALHO, M. A. P. et al. Aplicações da genética quantitativa no melhoramento de plantas autógamas. Lavras MG: UFLA, 2012b. 522 p.

SIBIYA, J. et al. Combining ability analysis for Phaeosphaeria leaf spot resistance and grain yield in tropical advanced maize inbred lines. Field Crops Research, Amsterdam, v. 120, n. 1, p. 86-93, 2011.

THANH, M. N. et al. Estimates of strain additive and non-additive genetic effects for growth traits in a diallel cross of three strains of giant freshwater prawn (Macrobrachium rosenbergii) in Vietnam. Aquaculture, Amsterdam, v. 299, n. 1/4, p. 30-36, 2010.

USHAKUMARI, R. N.; VAIRAN, C. R.; MALINI, $\mathrm{N}$. Studies on hybrid vigour and combining ability for seed yield and contributing characters in cowpea (Vigna unguiculata). Electronic Journal of Plant Breeding, Coimbatore, v. 1, n. 4, p. 940-947, 2010.

WU, H. X.; MATHESON, A. C. Reciprocal, maternal and nonmaternal effects in radiata pine diallel mating experiment on four Australia sites. Forest Genetics, Zvolen, v. 8, n. 3, p. 205-212, 2001.

This work is licensed under a Creative Commons Attribution-CC-BY https://creativecommons.org/licenses/by/4.0/ 